\title{
SOCIAL CAPITAL AS A SOFT FACTOR IN FACILITY LOCATION PLANNING
}

\author{
Birol MERCAN \\ Selçuk University, Turkey \\ Nadide Sevil HALICI \\ Selçuk University, Turkey
}

\begin{abstract}
The decision on the facility situation depends not only on traditional hard local factors such as market structure and proximity to customers, proximity to suppliers and raw materials, access to rail and air transportation, establishment costs but on the soft local factors (external economic factors-personal choices.) One of these factors is social capital. There is a growing literature in sociology and political science on the "social capital". Social capital is defined as networks together with shared norms, values and understandings that facilitate co-operation within or among groups. Empirical results show that more social capital and higher levels of trust are associated with bigger firms, and higher economic growth. In developing countries, the lack of social trust is the most important factor in front of developing. Many studies find a remarkable correlation between the trust in a country and the presence of large organizations and focused a correlation between a country's level of trust and its rate of growth.
\end{abstract}

\section{INTRODUCTION}

Many studies focus on the role of social capital as a key factor in reducing transaction costs in communities and enterprises and enabling people to work together more effectively. Enterprises and organizations can benefit from norms of trust embodied in different types of intra-firm or inter-firm networks. Reputation, familiarity and informal sanctions can complement the role of formal contracts and legal sanctions. Organizational culture and networks can constitute important intangible resources for performance. To develop the capacity and competence of an organization, greater stress has been placed in management studies on the value of relationships and group identity. Workers who feel that they are part of the organization and share its goals and values are more likely to contribute more effectively. A clustering of industries and networks can yield benefits by way of chance friendships, contacts and acquaintances. In this paper we will define concept of social capital and explore its economic functions, and make suggestions for how it can be increased.

\section{LOCATION PLANNING}

Location decisions can have a extensive effect on a firm's competitive advantage. For example, a firm might choose to locate a plant in new geographic region not only to reduce distribution costs, but also to create cultural ties between the firm and the local community. The relationships established may attract new business and improve the firm's market position in relation to distant competitors.

Location decisions are based on both economic and non economic factors (Evans, 1997,292). Table 1 is a list of important location factors include facility costs such as construction, utilities, insurance, taxes, depreciation and maintenance; operating costs, including fuel, direct labor and administrative personnel (which may vary considerably by location); and transportation costs, the costs associated with moving goods from their origins to the final destinations. Economic factors, especially construction costs, taxes and wage rates, vary by location. Low wage rates are a major reason many companies move factories to other countries. Many states offer tax incentives to entice companies to build plants there. Transportation costs can be a large proportion of the total delivered cost of a product, however and locating a plant far from sources of supply or customers can commit a company to significant transportation costs. Thus, the plant location decision must intend to minimize production and transportation costs.

Non economic factors include the availability of labor, transportation services and utilities; climate, community environment, and quality of life; and state and local politics. There must be a sufficient supply of labor to meet planned production levels; in addition, workers must have the appropriate skills. Labor intensive firms may want to locate where wage rates and costs of training are low. Some companies may require trucking service, while other firms may require rail service. Other firms need to be close to water transportation or major airports. All production activities require such services as electricity, water, and waste removal. For example, chemical-processing, paper and nuclear-power companies require large 
Table 1: Factors for Location Planning

\begin{tabular}{|c|c|c|c|c|}
\hline $\begin{array}{l}\text { LABOR } \\
\text { FACTORS }\end{array}$ & $\begin{array}{l}\text { TRANSPORTATION } \\
\text { FACTORS }\end{array}$ & $\begin{array}{l}\text { UTILITIES } \\
\text { FACTORS }\end{array}$ & $\begin{array}{l}\text { CLIMATE, COMMUNITY } \\
\text { ENVIRONMENT AND } \\
\text { QUALITY OF LIFE FACTORS }\end{array}$ & $\begin{array}{l}\text { STATE AND LOCAL } \\
\text { POLITICAL FACTORS }\end{array}$ \\
\hline $\begin{array}{l}\text { Labor } \\
\text { supply }\end{array}$ & $\begin{array}{l}\text { Closeness to } \\
\text { sources of supply }\end{array}$ & $\begin{array}{l}\text { Water } \\
\text { supply }\end{array}$ & $\begin{array}{l}\text { Climate and living } \\
\text { conditions }\end{array}$ & $\begin{array}{l}\text { Climate and living } \\
\text { conditions }\end{array}$ \\
\hline $\begin{array}{l}\text { Labor } \\
\text { management } \\
\text { relations }\end{array}$ & $\begin{array}{l}\text { Closeness to } \\
\text { markets }\end{array}$ & $\begin{array}{l}\text { Waste } \\
\text { disposal }\end{array}$ & Schools & Taxation policies \\
\hline $\begin{array}{l}\text { Ability to } \\
\text { retain labor } \\
\text { force }\end{array}$ & $\begin{array}{l}\text { Adequacy of } \\
\text { transportation } \\
\text { modes }\end{array}$ & $\begin{array}{l}\text { Power } \\
\text { supply }\end{array}$ & $\begin{array}{l}\text { Universities and research } \\
\text { facilities }\end{array}$ & Tax structure \\
\hline $\begin{array}{l}\text { Availability of } \\
\text { technical and } \\
\text { executive } \\
\text { personnel }\end{array}$ & $\begin{array}{l}\text { Costs of } \\
\text { transportation }\end{array}$ & $\begin{array}{l}\text { Fuel } \\
\text { availability } \\
\text { and cost }\end{array}$ & $\begin{array}{l}\text { Community attitudes } \\
\text { Community attitudes }\end{array}$ & $\begin{array}{l}\text { Opportunity for } \\
\text { highway advertising }\end{array}$ \\
\hline Labor rates & & Communications & Religious factors & \\
\hline
\end{tabular}

Source: Evans, James R. (1997), Production/ Operations Management, Quality, Performance and Value, West Publishing Company, Fifth Edition, USA, p.293

amounts of water for cooling and therefore would consider only locations near an abundant water supply. A favorable climate is good for employee well-being and morale. Taxes, the cost of living, and educational and cultural facilities are all important to employees, particularly if they are relocating. Community behaviors should also be evaluated. For example, industries that handle high-risk chemicals or radioactive substances are particularly susceptible to unfavorable public reaction and legislation and are less likely to locate in urban areas. Finally, the political attitudes of the state can be either favorable or unfavorable to locating there. Activities such as industrial development programs, revenue-bond financing, state industrial loans and tax inducements are often important factors in choices to locate in one state instead of another.

Location planning is typically conducted hierarchically. Tree basic decisions must be made: the regional decision, the community decision and the site decision. The regional decision involves choosing a general region of the country. In this era of globalization, various regions of the word might also be considered, such as Mexico, South America or the Pacific Rim. Factors that affect the regional decision include the locations of major customers and sources of materials and supply; labor availability and costs; and climate. The community decision involves selecting a specific city or community in which to locate. In addition to the factors cited for the regional decision, a company would consider managers' preferences, community services and taxes, available transportation systems, banking services and environmental impacts. Finally, the site decision involves the selection of a particular location within the chosen community. Site costs, proximity to transportation systems, utilities and zoning restrictions are among the factors to be considered. In other words all economic factors we mentioned before can be classified hard factors in location planning. But also there are many other soft or non economic factors that can affect this choice. For instance the history and culture, religion, the relations between families and firms can be effective in location planning also besides economic factors. One of these soft factors is social capital that can measure by trust.

Trust is a big issue in today's business world, since evidence suggests that trust between employees and employers has been waning. It is difficult, if not impossible, to have effective and productive working relationships without trust. Therefore, trust is critical for every business (Becton, et all, 2002).

\section{SOCIAL CAPITAL AS A SOFT FACTOR}

Economic developments presume not just the existence of formal institutions, but also certain norms or social values that promote exchange, savings, and investment. Thus, there is a cultural dimension to economic behavior. The importance of cultural factors for economic behavior has long been under dispute, with some social scientists-particularly economists-arguing that it constitutes a small and difficult-to-measure residual variable, and others asserting that social norms are constitutive of economic life itself. While culturalist explanations of development took a back seat to structural ones in the 1960s and 1970s, they have seen something of a revival in the 1980s and 1990 s as result of observing the economic perform- 
ance of culturally distinctive regions. Most recently, cultural factors have been discussed under the heading of "social capital". Social capital is a norm promoting social cooperation, which is seen to be productive of wealth as much as physical and human capital. A major research question for the future is how to measure social capital, and more broadly how to incorporate qualitative factors like social relationships and cultural habits into the mathematical models that dominate contemporary economics (Fukuyama, 2005).

Social capital refers to the institutions, relationships, and norms that shape the quality and quantity of a society's social interactions. Increasing evidence shows that social cohesion is critical for societies to prosper economically and for development to be sustainable. Social capital is not just the sum of the institutions which underpin a society - it is the glue that holds them together.

Social capital represents one of the most powerful and popular metaphors in current social science research. Broadly understood as referring to the community relations that affect personal interactions, social capital has been used to explain an immense range of phenomena, ranging from voting patterns to health to the economic success of countries. Literally hundreds of papers have appeared throughout the social science literature arguing that social capital matters in understanding individual and group differences and further that successful public policy design needs to account for the effects of policy on social capital formation (Durlauf, Fafchamps, 2004).

The meaning of social capital have a long intellectual history in the social sciences but the sense in which the term is used today dates back more than 80 years to the writings of Lyda J. Hanifan, then the superintendent of schools in West Virginia. Explaining the importance of community participation in enhancing school performance, Hanifan invoked the concept of social capital, describing it as those tangible substances [that] count for most in the daily lives of people: namely good will, fellowship, sympathy, and social intercourse among the individuals and families who make up a social unit. If [an individual comes] into contact with his neighbor, and they with other neighbors, there will be an accumulation of social capital, which may immediately satisfy his social needs and which may bear a social potentiality sufficient to the substantial improvement of living conditions in the whole community. After Hanifan the idea of social capital disappeared for several decades in 1930s by Alfred Marshall, in the 1950s by John Seeling, in the 1960 s by Jane Jacobs and in the 1970s by Glenn
Loury. None of these writers, interestingly, cited earlier work on the subject, but all used the same term to summarize the vitality and significance of community ties. The research by Coleman on education and by Putnam (1993) on civic participation and institutional performance, however, has provided the inspiration for most of the current work, which has since combined around studies in nine primary fields: families and youth behavior; schooling and education; community life (virtual and civic); work and organizations; democracy and governance; collective action; public health and environment; crime and violence; and economic development (Trentmann, 2003 and Woolcock, Narayan; 2000).

The central premise of social capital is that social networks have value. Social capital refers to the collective value of all "social networks" (who people know) and the inclinations that arise from these networks to do things for each other (norms of reciprocity).

The term of social capital emphasizes not just warm and cuddly feelings, buy a wide variety of quite specific benefits that flow the trust, reciprocity, information and cooperation associated with social Networks. Social capital creates value for the people who are connected and - at least sometimes- for bystanders as well. (www.bowlingalone.com)

Why social capital is is so important? Because social capital triggers (Kirmanoğlu, 2004);

1) High economic growth rates,

2) Effective institutional (public and ve civil) structure

3) Qualitative health services,

4) Low crime rates,

5) High schooling rates and high quality of education

We begin our search by listing a number of definitions that have been proposed by some of the most influential researchers on social capital. We begin with Coleman $(1990,304)$ who defines social capital as:

...social organization constitutes social capital, facilitating the achievement of goals that could not be achieved in its absence or could be achieved only at a higher cost.

Putnam et al $(1993,167)$ provides a similar characterization,

...social capital refers to features of social organization, such as trust, norms, and networks that can improve the efficiency of society.

Putnam's concept of social capital has three compo- 
nents: moral obligations and norms, social values (especially trust) and social networks (especially voluntary associations). Putnam's central thesis is that if a region has a well-functioning economic system and a high level of political integration, these are the result of the region's successful accumulation of social capital. In the United States many social problems are caused by the decline of social capital; a tendency that has been going on for the last three decades. Adam Seligman also writes in the same spirit: "The emphasis in modern societies on consensus (is) based on interconnected networks of trust - among citizens, families, voluntary organizations, religious denominations, civic associations, and the like. Similarly the very "legitimating" of modern societies is founded on the "trust" of authority and governments as generalizations" (Siisiäinen, 2000).

Both definitions emphasize the beneficial effects social capital is assumed to have on social aggregates. According to these definitions, social capital is a type of positive group externality. Coleman's definition suggests that the externality arises from social organization. Putnam's definition emphasizes specific informal forms of social organization such as trust, norms and networks.

In his definition of social capital, Fukuyama (Durlauf, Fafchamps, 2004) argues that only certain shared norms and values should be regarded as social capital: Social capital can be defined simply as the existence of a certain set of informal rules or norms shared among members of a group that permits cooperation among them. The sharing of values and norms does not in itself produce social capital, because the values may be the wrong ones. The norms that produce social capital must substantively include virtues like truthtelling, the meeting of obligations, and reciprocity.

Fukuyama focuses on the role of trust as a key mediating factor in lowering "transaction costs" in communities and enterprises and enabling people to work together more effectively (Social Capital Forum Report).

But there is also an older concept of social capital, developed by Pierre Bourdieu in the 1970s and early 1980s. Bourdieu's concept is connected with his theoretical ideas on class. He identifies three dimensions of capital each with its own relationship to class: economic, cultural and social capital. These three resources become socially effective, and their ownership is legitimized through the mediation of symbolic capital. Bourdieu's concept of social capital puts the emphasis on conflicts and the power function (social relations that increase the ability of an actor to advance her/his interests). Social positions and the division of economic, cultural and social resources in general are legitimized with the help of symbolic capital. From the Bourdieuan perspective, social capital becomes a resource in the social struggles that are carried out in different social arenas (Siisiäinen, 2000).

For instance; when a group of neighbors informally keep an eye on one another's homes, that's social capital action. When a tightly knit community of Hassidic Jews trade diamonds without having to test each gem for purity, that's social capital in action. Social capital can be found in friendship networks, neighborhoods, schools, clubs, civic associations and even cafes. The motto in Cheers "where everybody knows your name" captures one important aspect of social capital (www.bowlingalone.com).

\section{Concepts about the Term of Social Capital}

We highlight some of the most pertinent topics for social capital as it relates to development (Wordbank, 2005a).

$\checkmark$ Crime/violence: Shared values and norms can reduce or keep low the level of community violence. People who have informal relations with their neighbors can look out for each other and 'police' their neighborhoods

$\checkmark$ Economics \& trade: There is increasing evidence that trade at the macro level is influenced by social capital --a common property resource whose value depends on the level of interaction between people.

$\checkmark$ Education: Considerable evidence shows that family, community and state involvement in education improves outcomes.

$\checkmark$ Environment: Common property resource management entails cooperation with a view to ensure the sustainability of resources for the benefit of all community members, in the present and in the future.

$\checkmark$ Finance: A stable, secure and equitable financial system is a precursor for sustainable growth.

$\checkmark$ Health, nutrition \& population: Recent research shows that the lower the trust among citizens, the higher the average mortality rate.

$\checkmark$ Information technology: Information technology has the potential to increase social capital - and in particular bridging social capital which connects actors to resources, relationships and information beyond their immediate environment.

$\checkmark$ Poverty \& economic development: Development and growth specialists are uncovering the importance of social cohesion for societies to prosper economically and for development to be sustainable. 
$\checkmark$ Rural development: Social capital is significant because it affects rural people's capacity to organize for development. Social capital helps groups to perform the following key development tasks effectively and efficiently.

$\checkmark$ Urban development: Urban areas, with their anonymity and fast pace, can be unconducive to societal cooperation. Social capital and trust are more difficult to develop and sustain in large groups.

$\checkmark$ Water supply \& sanitation: Social capital contributes to the sharing of information about sanitation as well as the building of community infrastructure.

Because of the relation between all these factors and development, many firms consider these factors in location planning.

\section{Social capital works through multiple channels} (www.bowlingalone.com):

1) Information flows (e.g. learning about jobs, learning about candidates running for office, exchanging ideas at college, etc.) depend on social capital

2) Norms of reciprocity (mutual aid) are dependent on social networks.

a) Bonding networks that connect folks who are similar sustain particularized (in-group) reciprocity. b) Bridging networks that connect individuals who are diverse sustain generalized reciprocity.

3) Collective action depends upon social networks (e.g., the role that the black church played in the civic rights movement) although collective action also can foster new networks.

4) Broader identities and solidarity are encouraged by social networks that help translate an "I" mentality into a "we" mentality.

\section{Utility of Social Capital to Firms}

Social capital helps to internalize externalities for which there is no market and where transactions costs are too high to write complete contracts. Informal credit arrangements, financial and in-kind assistance to neighbors and friends or investments in public goods are just one of the many examples of social capital (Mobius, 2004). Social capital benefits firms by two main ways: (Wordbank, 2005b)

\section{Social Capital Reduces Transaction Costs}

Firms benefit from social capital because it facilitates cooperation and coordination which minimize transaction costs, such as negotiation and enforcement, imperfect information and layers of unnecessary bureaucracy. Reciprocal, interdependent relationships- -models of social capital--embody enforcement.

$\checkmark$ In his study of flexible production systems, Lorenz found that without a cooperative agreement, an automobile company or a parts manufacturer may be able to take advantage of the other through strategically altering prices. Social capital helps firms protect themselves against such risks in a cost-efficient manner.

\section{Social Capital Provides a Competitive Edge}

Efficiency gains in time and information allow more resources to be devoted to producing and marketing a better product at a higher volume.

$\checkmark$ Humphrey and Schmitz highlight how "trust based relations between economic agents have been seen as part of the competitive advantage of manufacturing enterprises in Germany, Japan and parts of Italy..."

\section{The Effects of Social Capital}

The effects of social capital to firms can classified in four topics (Wordbank, 2005b)

\section{* Within a Firm}

Social capital promotes greater coordination among individuals and between departments. Teamwork can enhance efficiency and quality in small companies as well as multinational corporations. Social capital within and beyond the firm improve morale and enhance productivity.

$\checkmark$ Workers and shareholders in a firm are likely to feel an increased sense of pride in their work if they are part of an entity which strives to make a positive contribution to its surrounding communities - communities which are often home to firm staff.

\section{* Among Firms}

Trust is the foundation for cooperation between enterprises. Businesses banding together in a joint effort are able to establish deeper relationships with one another which can be accessed in the future for other business projects beyond the scope of the original group. For example, research and design costs can be shared when there is a collaborative agreement between otherwise rivalrous firms.

$\checkmark$ This is evident in niche markets, such as software development, where entrepreneurs take advantage of economies of time, by sharing information, and adapting quickly to changing demands. Marketing and lobbying are other opportunities for efficiency 
and effectiveness gains through cooperation.

\section{* Across Sectors}

Recognizing the importance of cross-sectoral partnerships for sustainable business as well as sustainable development, the Prince of Wales formed his Business Leaders Forum to promote synergy, interdependence and social capital across the public, private and civil society sectors.

Indian Business \& Community Partnership Trust is a coalition of businesses working across sectors to promote social and economic development in India. Such partnerships may translate into better access and more influence during policy debates and increased support from community-based organiza- tion; both are critical components of a successful business initiative.

* Within Society

Societal levels of social capital impact businesses positively or negatively. Social capital affects the types of firms which are successful within a society and creates either an enabling or disabling environment for private sector development.

$\checkmark$ Business endeavors which have positive spill-over effects for the community can increase people's level of participation in society and the goodwill they feel towards the public and private sectors. Social cohesion is a key enabling condition for stable politics and profitable business.

Figure 1: Interaction of Social Capital and Economic Development

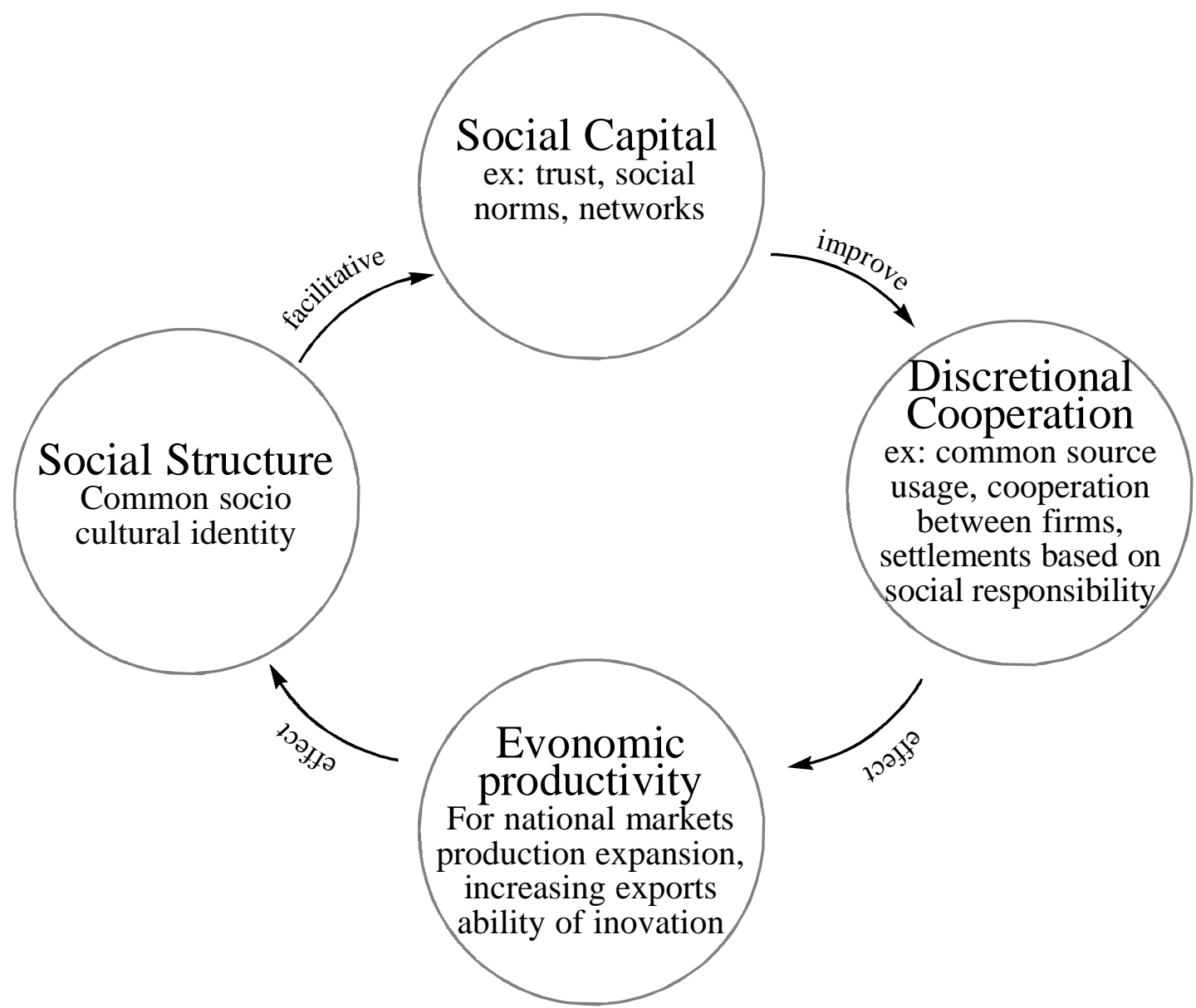

Source: Jörg Meyer - Stamer, Strategien und Instrumente lokaler Wirtschafts- und Beschäftigungsförderung zur Schaffung von Einkommen und Beschäftigung für arme Bevölkerungsgruppen: Land und Stadt, Cluster und Sozialkapital, Studie für das GTZ-Projekt "Armutsminderung durch Wirtschafts- und Beschäftigungsförderung" s. 29 


\section{Increasing the Stock of Social Capital?}

The discussion of where social capital comes from should be informative to policymakers who want to increase the stock of social capital in a given country. States can both do some positive things to create social capital, and forebear from doing others that deplete a society's stock. Fukuyama make four suggestions to increase social capital (2000):

First, states do not have many obvious levers for creating many forms of social capital. Social capital is frequently a byproduct of religion, tradition, shared historical experience, and other factors that lie outside the control of any government. Public policy can be aware of already existing forms of social capital-for example, the social networks used to develop information for micro lending-but it cannot duplicate the effect of religion as a source of shared values. Policymakers also need to be aware that social capital, particularly when associated with groups that have a narrow radius of trust-can produce negative externalities and be detrimental to the larger society.

Second, the area where governments probably have the greatest direct ability to generate social capital is education. Educational institutions do not simply transmit human capital; they also pass on social capital in the form of social rules and norms. This is true not just in primary and secondary education, but in higher and professional education as well. Doctors learn not just medicine but the Hippocratic Oath; one of the greatest safeguards against corruption is to give senior bureaucrats high-quality professional training and to create an esprit de corps among this elite.

Third, states indirectly foster the creation of social capital by efficiently providing necessary public goods, particularly property rights and public safety. Private property rights protection is very inferior to the state-supplied version, since there is nothing to prevent these private providers from getting into a host of other illegal activities as well. There are also economies of scale in the deployment of coercive force used to enforce property rights. People cannot associate, volunteer, vote or take care of one another if they have to fear for their lives when walking down the street. Given a stable and safe environment for public interaction and property rights, it is more likely that trust will arise spontaneously as a result of iterated interactions of rational individuals.

Fourth, states can have a serious negative impact on social capital when they start to undertake activities that are better left to the private sector or to civil soci- ety. The ability to cooperate is based on habit and practice; if the state gets into the business of organizing everything, people will become dependent on it and lose their spontaneous ability to work with one another.

\section{CONCLUSION}

The term social capital is widely used, but it has muzzy meaning. This paper has centered some definitions of social capital. We argued that social capital's function is as a support of trust, and that trust is the coordinating mechanism of firms in networks. Social capital leads firms to clustering in particular region because of presence of social capital. The key feature of the definition of social capital developed here is in its role in the support of trust relations among economic actors. As it is well known, trust is the main factor affects economic relations among economic actors. Social capital refers to the institutions, relationships, and norms that shape the quality and quantity of a society's social interactions. Increasing evidence shows that social cohesion is critical for societies to prosper economically and for development to be sustainable. Social capital is not just the sum of the institutions which underpin a society - it is the glue that holds them together. Consequently social capital is so important for firms for location planning. Therefore efforts to increasing the social capital must be supported. 


\section{REFERENCES}

Becton, Clayton, Wysocki Allen, and Kepner Karl (2002), Building Teamwork and the Importance of Trust in a Business Environment, Department of Food and Resource Economics, Florida Cooperative Extension Service, Institute of Food and Agricultural Sciences, University of Florida, Gainesville, FL.

Fukuyama, F. (2005), Culture and Economic Development (Cultural Concern Essay), http://www.sais-

jhu.edu/fukuyama/articles/Culture_development.pdf

Evans, James R. (1997), Production/ Operations Management, Quality, Performance and Value, West Publishing Company, Fifth Editon, USA

Durlauf, Steven N. and Fafchamps, Marcel (2004), Social Capital, The Centre for the Study of African Economies Working Paper Series, Paper 214

Trentmann, Claudia (2003), Sozialkapital in ländlichen Basisorganisationen Haitis. Potenzial zur Minderung der Armut?, Dissertation zur Erlangung des Doktorgrades (Dr.rer.soc) des Fachbereichs Sozial und Kulturwissenschaften der Justus- LiebigUniversität Gie ßen

Coleman, J. (1990) Foundations of Social Theory. Cambridge, MA: Belknap Press of Harvard University Press

Putnam, R. and R. Leonardi and R. Nanetti, (1993), Making Democracy Work: Civic

Traditions in Modern Italy, Princeton: Princeton University Press.

Siisiäinen, Martti (2000), Two Concepts of Social Capital: Bourdieu vs. Putnam, ISTR Fourth International Conference, Trinity College, Dublin, Ireland

Putnam, R. (2000), Bowling Alone: The Collapse and Revival of American Community New York: Simon and Schuster.

Mobius, Markus M., Anh, Do Quoc and Rosenblaty, Tanya S. (2004), Social Capital in Social Networks, http://www.nber.org/ rosenbla/harvardexp/socialpref.pdf

Woolcock, Michael and Narayan, Deepa (2000), Social Capital: Implications for Development Theory, Research, and Policy, The World Bank Research
Observer, vol. 15, no:2

Kirmanoğlu, Hasan (2004), Sosyal Sermaye ve Geleceği Şekillendirmek, Önce Kalite, Yıl: 12 Sayı: 83

Karagül, Mehmet (2002), Beşeri Sermayenin İktisadi Gelişmedeki Rolü ve Türkiye Boyutu, Afyon Kocatepe Üniversitesi Yayın No: 37, Ankara

Fukuyama, Francis (2000), Social Capital and Civil Society, IMF Working Paper, WP/00/74

The Policy Implications of Social Capital, The National Economic And Social Forum, Forum Report No. 28 May 2003

Putnam, Robert D.(1993) "The Prosperous Community: Social Capital and Public Life The American Prospect 13

Social Capital and Firms (2005b), http://www1.worldbank.org/prem/poverty/scapital/so urces/firm1.htm

Topics Relevant to Social Capital (2005a), http://www1.worldbank.org/prem/poverty/scapital/to pic/index.htm

Social Capital: What is it? http://www.bowlingalone.com/socialcapital.php3 